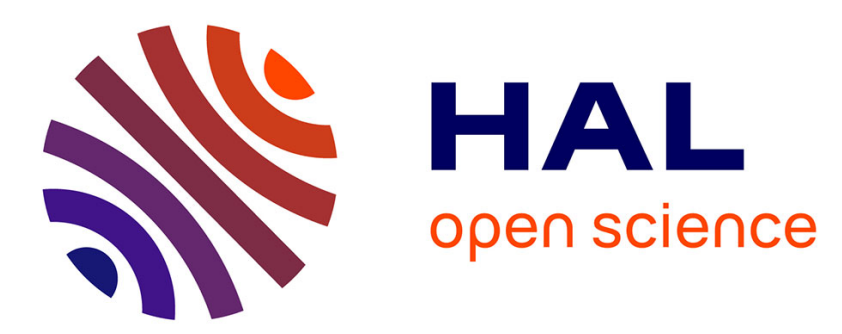

\title{
Food web structure variability in the surface layer, at a fixed station influenced by the North Western Mediterranean Current
}

\author{
Urania Christaki, France van Wambeke, Epaminondas D Christou, Pascal \\ Conan, Raymond Gaudy
}

\section{To cite this version:}

Urania Christaki, France van Wambeke, Epaminondas D Christou, Pascal Conan, Raymond Gaudy. Food web structure variability in the surface layer, at a fixed station influenced by the North Western Mediterranean Current. Hydrobiologia, 1996, 321, pp.14 - 19. hal-01829994

\section{HAL Id: hal-01829994 https://hal.science/hal-01829994}

Submitted on 4 Jul 2018

HAL is a multi-disciplinary open access archive for the deposit and dissemination of scientific research documents, whether they are published or not. The documents may come from teaching and research institutions in France or abroad, or from public or private research centers.
L'archive ouverte pluridisciplinaire HAL, est destinée au dépôt et à la diffusion de documents scientifiques de niveau recherche, publiés ou non, émanant des établissements d'enseignement et de recherche français ou étrangers, des laboratoires publics ou privés. 


\title{
Food web structure variability in the surface layer, at a fixed station influenced by the North Western Mediterranean Current
}

\author{
Urania Christaki $^{1,2}$, France Van Wambeke ${ }^{2}$, Epaminondas D. Christou ${ }^{3}$, Pascal Conan $^{4} \&$ \\ Raymond Gaudy ${ }^{1}$ \\ ${ }^{1}$ Centre d'Océanologie de Marseille, Station marine d'Endoume, Rue de la Batterie des Lions, CNRS URA 041, \\ 13007 Marseille, France \\ ${ }^{2}$ Microbiologie Marine, C.N.R.S., U.P.R. 223, Campus de Luminy, Case 907, 13288 Marseille Cedex 9, France \\ ${ }^{3}$ National Centre for Marine Research. Aghios Kosmas Hellinikon, GR-16004 Greece \\ ${ }^{4}$ Centre d'Océanologie de Marseille, Campus de Luminy, CNRS URA 041, 13288 Marseille Cedex 9, France
}

Received 6 October 1994; in revised form 13 July 1995; accepted 13 July 1995

Key words: microbial food web, diel cycles, mesozooplankton, NW Mediterranean Sea

\begin{abstract}
The structure of the planktonic community and the influence of mesozooplankton migration on the microbial food web were investigated during six diel studies from June 92 to June 93 in the surface waters of a station in the North-Western Mediterranean Sea. Each diel study consisted of sampling at 5 and $40 \mathrm{~m}$ every $3 \mathrm{~h}$ over $24 \mathrm{~h}$. Most of the times diel cycles did not show any convincing diel patterns in any of the variables studied. Clear zooplankton migration was evident in only two diel studies.

The ratio of heterotrophic/autotrophic biomasses varied from 0.68 to 3.0 , with a strong dominance of the heterotrophic biomass under oligotrophic conditions. Differences in food web structure were probably related to the influences of coastal water and the North-Western Mediterranean Current. Thus we found that the planktonic food web variability relatable to hydrodynamic variability, to be greater than diel variability. However, very large differences in food web structure among dates were evident. For example proportion of Chl $a$ found in the $<10 \mu \mathrm{m}$ fraction varied from 18 to $96 \%$.
\end{abstract}

\section{Introduction}

The diel migration of zooplankton is an extensively studied phenomenon, while a restricted number of diel studies in microbial communities exists (Davis et al., 1985; Sorokin et al., 1985; Fuhrman et al., 1985; McManus \& Fuhrman, 1990). Some authors have hypothesized on a possible role of copepod migration on microbial communities (Sorokin et al., 1985; Bochdansky et al., 1995), while others have disputed it (Fuhrman et al., 1985). It has been shown that, nocturnal vertical migration and activity of zooplankton influences the content and composition of biological and chemical constituents in near surface layers (Eppley et al., 1981; Riemann et al., 1986; Herndl \& Malacic, 1987). However, no attempt has been made to follow diel variations of microbial communities and mesozoo- plankton concurrently during several diel cycles. Thus, the question of whether - or not - diel rhythms in microbial communities exist and whether - or not - zooplankton migration has a direct effect on these communities it is still largely open.

Additionally, on seasonal and ocean wide scales, pelagic food web structure is influenced by hydrodynamics (Le Fèvre \& Frontier, 1988). However, hydrodynamic discontinuities also occur on finer temporal and horizontal scales (Kiørboe et al., 1990; Piontkovski et al., 1995), such as those observed in the North-Western Mediterranean Sea (Conan \& Millot, in press) and could influence diel cycles.

The goal of this study was to asses the structure and variability of the planktonic food web, at a fixed station influenced by the North-Western Mediterranean Current (NWMC) and to provide evidence of the exis- 
tence (or not) of diel cycle in microbial communities with emphasis on the influence of mesozooplankton migration on the microbial food web. This fixed geographical position $\left(43^{\circ} 02 \mathrm{~N}, 05^{\circ} 12 \mathrm{E}, 1000 \mathrm{~m}\right.$ depth) was chosen in order to include our data in the context of a multidisciplinary study (PNOC Program: 'Programme National d'Océanographie Côtière') involving the behaviour of the NWMC.

\section{Materials and methods}

Six diel cycles were undertaken at a fixed station $\left(43^{\circ}\right.$ $02 \mathrm{~N}, 05^{\circ} 12 \mathrm{E}, 1000 \mathrm{~m}$ depth) between June 92 and June 93. The position of the main vein of the NorthWestern Mediterranean Current was determined along a north-south transect of 7 stations crossing it perpendicularly. Hydrographic measurements were made using a conductivity-temperature depth probe (CTD type SBE 19, 'Seacat profiler Seabird').

The biological variables measured included chlorophyll $a$, concentration of bacteria, phototrophic and heterotrophic nanoflagellates, ciliates and mesozooplankton. Water samples were collected at 3-hour intervals over a $24 \mathrm{~h}$ period, with thoroughly cleaned 81 Niskin bottles, from 5 and $40 \mathrm{~m}$ depths. Sampling always started at $12 \mathrm{~h} 00$. Mesozooplankton samples were collected by vertical hauls $(50-0 \mathrm{~m})$ using a $200 \mu \mathrm{m}$ standard WP2 net. For determination of chlorophyll $a$, unfiltered, 10 and $3 \mu \mathrm{m}$ (Nuclepore) filtrates from each depth were collected on Whatman GF/F filters and analyzed by fluorometry (Strickland and Parsons 1972) on a 'Turner designs' fluorometer. Samples for the enumeration of bacteria and protozoa were fixed with $0.2 \mu \mathrm{m}$ filtered formalin (final concentration $2 \% \mathrm{w} / \mathrm{v}$ ). Subsamples for bacteria and flagellates, $5 \mathrm{ml}$ and $20 \mathrm{ml}$ respectively, were filtered within $48 \mathrm{~h}$ of sampling on black Nuclepore filters $(0.2 \mu \mathrm{m}$ for bacteria, $0.8 \mu \mathrm{m}$ for nanoflagellates) that were subsequently stained with DAPI (4.6-diamidino2-phenylindole, final concentration $25000 \mu \mathrm{g} \mathrm{l}^{-1}$ ). For bacteria (BACT) enumeration, epifluorescence microscopy coupled with an image analysis system was used; up to 40 fields containing $30-70$ bacteria per field were counted and the coefficient of variation (CV) across fields was within 6-16\%. Cyanobacteria, which are dominated by Chroococcoid forms containing phycoerythrin (Partensky pers. comm.) were counted on the same $0.2 \mu \mathrm{m}$ filters under blue light excitation. We classified as HNAN all eucaryotic non pigmented organisms less than $10 \mu \mathrm{m}$ in size, and distin- guished chlorophyll containing cells (PNAN) by their red autofluorescence. Nanoflagellates were classified into three size categories during counts, with an ocular micrometer. Small sized populations are dominated by flagellates (Booth et al., 1993). However, many flagella fall off during fixation, thus non-flagellate (e.g. coccoid, amoebic forms) were grouped together with flagellates. Random $10 \mathrm{~mm}$-strips (160 $\mu \mathrm{m}$ width) were counted for flagellates. About $60-100$ flagellates were counted and measured per filter, average CV across strips ranged from 10 to $22 \%$. Ciliates (CIL) and phytoplankton $>10 \mu \mathrm{m}$, preserved with Lugol $(100 \mathrm{ml}$ samples) were counted on an inverted microscope by Utermöhl (1958) counting technique. Two to three counts for every depth and per diel cycle were made for these organisms. The retained mesozooplankton (ZOO) from the $200 \mu \mathrm{m}$ mesh nets were divided in half. The first fraction was fixed with formalin for counting and identification. The second one was used for dry weight analysis.

\section{Biomass determinations and bacterial production}

Biomass of organisms were calculated from conversion factors as follows: Bacterial abundance data were converted to biomass using $20 \mathrm{fg} \mathrm{C}^{\mathrm{C}}$ cell $^{-1}$ (Lee \& Fuhrman, 1987). Cyanobacteria were dominated by coccoid forms with diameters ranging from 0.8 to $1.2 \mu \mathrm{m}$ thus a median diameter of $1 \mu \mathrm{m}$ was used for calculation of cell volumes. An average cell volume was determined in each of the PNAN and HNAN size categories: $8.2 \mu \mathrm{m}^{3}$ for $<5 \mu \mathrm{m}$ class, $65.4 \mu \mathrm{m}^{3}$ for 5-7 $\mu \mathrm{m}$ class and $882 \mu \mathrm{m}^{3}$ for the $>7 \mu \mathrm{m}$ size class. CIL (mainly oligotrichous) were divided into 3 main categories: $1767 \mu \mathrm{m}^{3}$ for $<20 \mu \mathrm{m}$ class, $4186 \mu \mathrm{m}^{3}$ for 20-50 $\mu \mathrm{m}$ class and $23550 \mu \mathrm{m}^{3}$ for $>50 \mu \mathrm{m}$ class. Biovolume- carbon conversion factors were $250 \mathrm{fg} \mathrm{C}$ $\mu \mathrm{m}^{-3}$ for CYANO (Kana \& Glibert, 1987), $220 \mathrm{fg}$ $\mathrm{C} \mu \mathrm{m}^{-3}$ for HNAN and PNAN (Børsheim \& Bratbak, 1987), $190 \mathrm{fg} \mathrm{C} \mu \mathrm{m}^{-3}$ for CIL (Putt \& Stoecker, 1989). Mesozooplankton (ZOO) biomass was estimated as dry weight, which were then converted into carbon units assuming a $40 \%$ carbon content (Gaudy, unpublished data). The carbon:chlorophyll $a(\mathrm{C}: \mathrm{Chl} a)$ ratio was assumed to be 50 , according to the value usually used for oceanic water (Fuhrman et al., 1989).

Bacterial production was estimated by the thymidine method (Fuhrman \& Azam, 1982) during the two last studies (May and June 93, details are given in Van Wambeke et al., in press). 
Table 1. Hydrographic and plankton community characteristics during the diel cycles.

\begin{tabular}{|c|c|c|}
\hline Date & Hydrographic characteristics & Plankton community characteristics \\
\hline $\begin{array}{l}\text { 14-18 } \\
\text { June } 92\end{array}$ & $\begin{array}{l}\text { Station located in the inner edge of the core } \\
\text { current (NWMC). } \\
\text { Possible frontal influence }\end{array}$ & $\begin{array}{l}\text { Dominance of autotrophic biomass } \\
\text { diatoms }>10 \mu \mathrm{m}\end{array}$ \\
\hline $10-11$ & NWMC located offshore & Dominance of autotrophic biomass \\
\hline October 92 & Station influenced by coastal waters & $\begin{array}{l}\text { Dominance in number }(80 \%) \text { of } \\
\text { autotrophs }<10 \mu \mathrm{m}\end{array}$ \\
\hline $\begin{array}{l}10-11 \\
\text { December } 92\end{array}$ & $\begin{array}{l}\text { Station located in the inner edge of the NWMC. } \\
\text { Station influenced by coastal waters }\end{array}$ & Dominance of autotrophic biomass \\
\hline $1-2$ & NWMC situated near the coast & Dominance of heterotrophic biomass \\
\hline May 93 & Station influenced by open sea waters & Oligotrophic situation \\
\hline $\begin{array}{l}26-27 \\
\text { June } 93\end{array}$ & Station located near the core of the current & $\begin{array}{l}\text { Dominance of heterotrophic biomass } \\
\text { Oligotrophic situation }\end{array}$ \\
\hline
\end{tabular}

\section{Results}

\section{Hydrographic characteristics}

Each cruise was described by a distinct hydrodynamic structure (summarized in Table 1). During the two cruises of June 92, the seasonal thermocline was well established at a depth of around $20 \mathrm{~m}$. The station was located near the inner edge of the core of the North-Western Mediterranean Current (NWMC) and was marked by a weak velocity $\left(\approx 15 \mathrm{~cm} \mathrm{~s}^{-1}\right)$. In October, the thermocline deepened $(50 \mathrm{~m})$. The NWMC was located further offshore, the inner edge being $45 \mathrm{~km}$ from the coast. The station was influenced by a coastal west-east geostrophic current which was somewhat colder and less salty $\left(<17.4{ }^{\circ} \mathrm{C} ; 37.1\right)$ than the NWMC $\left(\approx 17.5^{\circ} \mathrm{C}, 37.3\right)$. In December, the NWMC deepened and increased in velocity due to the winter conditions, even though a weak thermocline persisted at $50 \mathrm{~m}$. The station was again located in the inner edge of the current. The thermal structure indicated that the station was influenced by coastal waters. In May 93, the water column was stratified, the NWMC was extremely superficial and pushed up against the coast; the station was influenced by the open sea waters. In June 93 , the hydrographic structure was represented by a well established thermocline. The station was located near the core of the current. The NWMC vein was narrow $(\approx 5 \mathrm{~km})$ and its velocity was weak $(\approx 13 \mathrm{~cm}$ $s^{-1}$.

\section{Mesozooplankton composition and biomass}

The highest ZOO concentration (mean: 3225 ind. $\mathrm{m}^{-3}$, biomass: $11.9 \times 10^{3} \mu \mathrm{g} \mathrm{C} \mathrm{m}^{-3}$, Table 2) was observed in May and the lowest in December (mean: 257 ind $\mathrm{m}^{-3}$, biomass: $1.05 \times 10^{3} \mu \mathrm{g} \mathrm{C} \mathrm{m}^{-3}$ ). Copepods dominated the $\mathrm{ZOO}$ population, from $60 \%$ in June 92 to $96 \%$ in May 93. Four copepod genera - Clausocalanus spp., Paracalanus spp. (almost exclusively $P$. parvus), Oithona spp. (O. plumifera and $O$. sinilis) and Centropages spp. (almost exclusively $C$. typicus) - prevailed in the copepod community. A classical diel migration pattern of $\mathrm{ZOO}$ with more animals in the surface layers during night hours was obtained in May and June 93 (Fig. 1a). In October 92, ZOO abundance increased slightly during the night. In June 1992 zooplankton (ZOO) abundance did not increase during night hours. In December 92 only 3 zooplankton samples were collected because of bad weather (Fig. 1a).

\section{Diel patterns of chloropyll a concentration,} nanoflagellates, bacterial abundance and production, variability between and within diel cycles

Chloropyll $a$ concentration showed important variations. During the two diel cycles carried out in June 92 , high Chl $a$ values were recorded mainly in the subsurface layer $(5 \mathrm{~m})$ from 12:00 to 15:00 on 14 June (up to $5.1 \mathrm{Chl} a \mathrm{l}^{-1}$, Table 2) and from 09:00 to 12:00 on 18 June 92 (up to $4.3 \mu \mathrm{g} \mathrm{Chl} a \mathrm{l}^{-1}$. High diatom abun- 


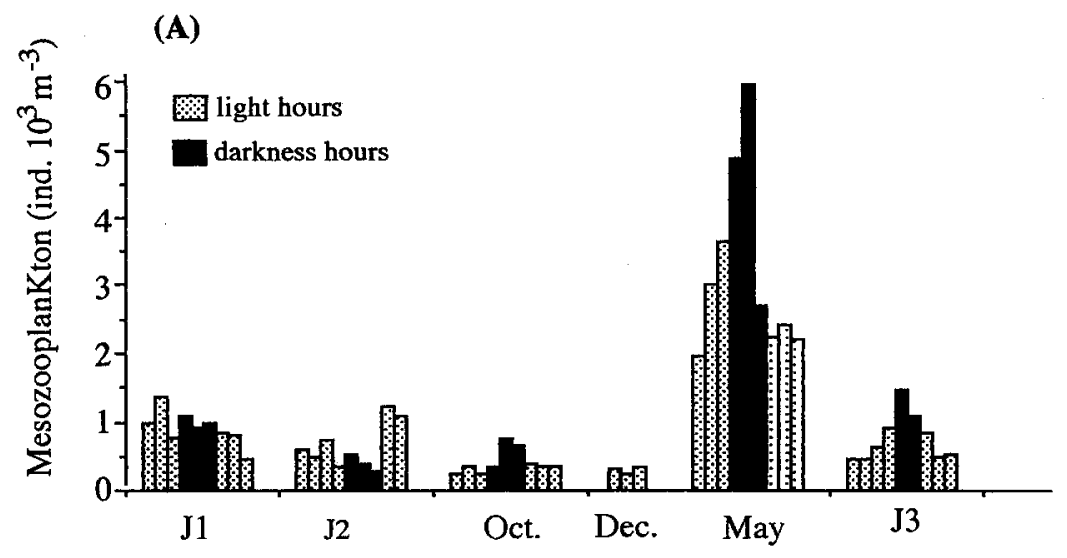

(B)

1-2 May1993

26-27 June 1993
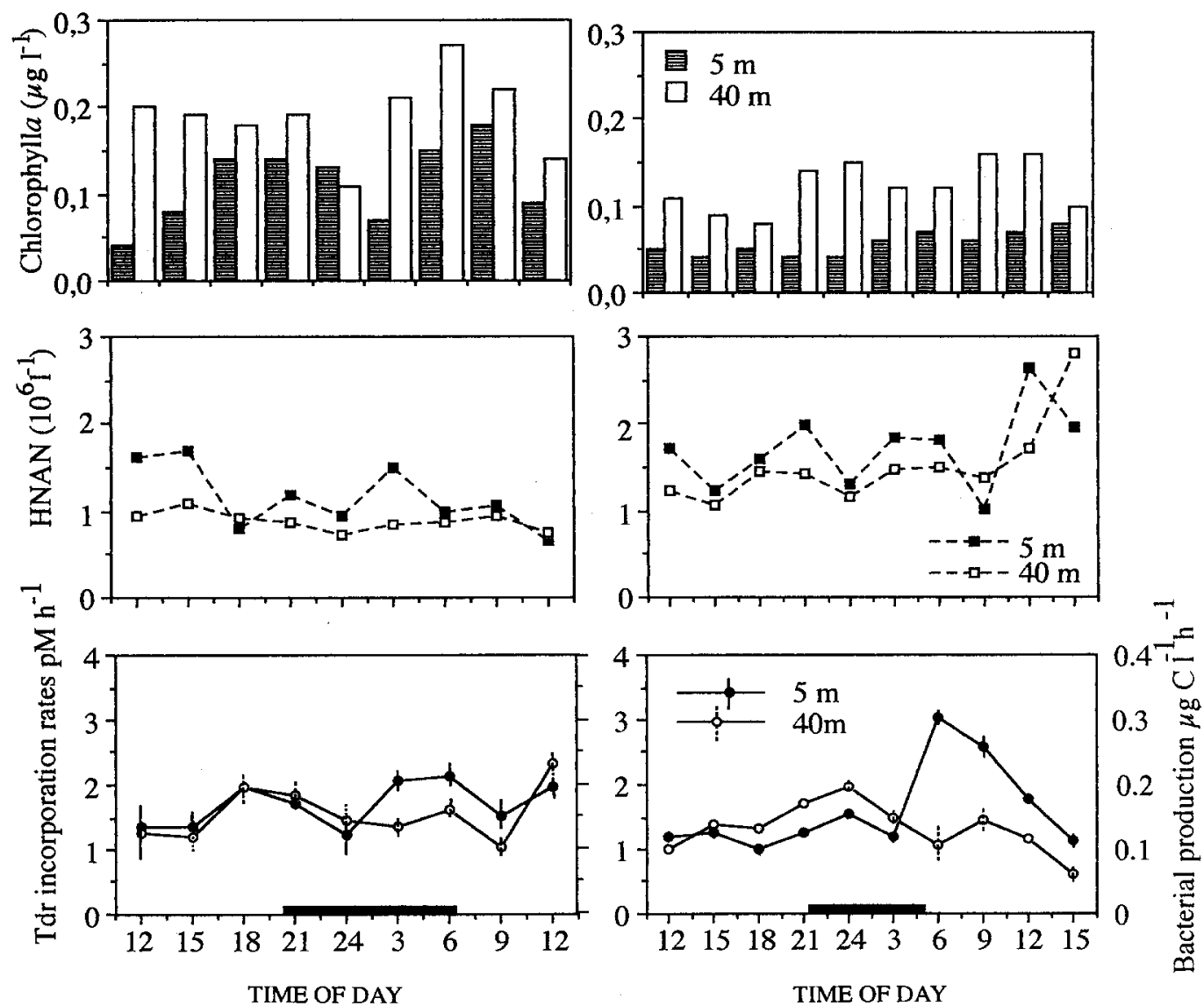

Figure 1. A: Diel evolution of mesozooplankton abundance, sampling every 3 hours, first sample at $12 \mathrm{~h} 00$. $\mathrm{J} 1=14-15 \mathrm{June} 92$, J2=17-18 June 92, Oct $=$ October 92, Dec = December 92 (only 3 samples for mesozooplankton because of bad weather), May = May 93, J3=June 93. B: Diel evolution of chloropyll $a$, heterotrophic flagellate abundance and $\left[\right.$ methyl $\left.{ }^{3} \mathrm{H}\right]$-thymidine (Tdr) incorporation rates are given for May and June 93 diel studies. The right- hand scale indicates the bacterial production $\left(\mu \mathrm{g} \mathrm{Cl}^{-1}\right)$, assuming $510^{18}$ bacteria produced.mol Tdr $^{-1}$ (empirical convesion factor, Van Wambeke et al., in press) and $20 \mathrm{fg} \mathrm{C}_{\text {. bacteria }}{ }^{-1}$, vertical bars indicate the values of the duplicate samples. Heavy lines on $\mathrm{x}$-axis indicate hours of darkness. 
Table 3. Relative abundance and biomass of different size classes of nanoflagellates, heterotrophic (HNAN) and phototrophic (PNAN). Average data from the six diel cycles \pm standard deviation.

\begin{tabular}{|c|c|c|c|c|c|c|c|}
\hline . & कि & 冚 & $8 \%$ & 30 & to & గైని & कूँ \\
\hline & 迷 & $\exists \bar{\top}$ & דర: & RT & Rก & 象展 & Rn \\
\hline & & $\underline{7}$ & $\mathrm{FH}$ & శ్గి గ్ & 88 & $8 \%$ & $9 \widetilde{7}$ \\
\hline & 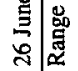 & $\begin{array}{l}0 \\
0 \\
0 \\
0 \\
0\end{array}$ & 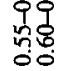 & 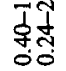 & 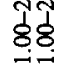 & 南余 & สิธ \\
\hline & 足 & to & $=\pi$ & man & $\therefore=$ & 总商 & Ft \\
\hline & ส & & & & $n \infty$ & तo & \\
\hline & $\frac{\mathrm{s}}{2}$ & 03 & 80 & ${ }_{i}$ & $=\infty$ & Nర & \\
\hline & 2 & กั & 음 & 에요 & విం & 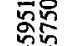 & \\
\hline & $\begin{array}{l}\Sigma \\
\Sigma \\
\end{array}$ & $\frac{1}{0}$ & 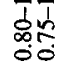 & 总 & $\begin{array}{l}5 \pi \\
0 \pi \\
0 \\
00\end{array}$ & $\begin{array}{l}\text { o. } \\
\text { go }\end{array}$ & 80 \\
\hline & 0 & $\ddot{0} \stackrel{+}{0}$ & 要 & :3. & $\overrightarrow{0} 00$ & 웜 & \\
\hline & 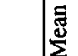 & $=5$ & 于. & is & of & చ్రం & \\
\hline & & ஜి గి & 87 & ৪ุণ & त्ष & $2 \infty$ & \\
\hline & 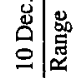 & $\begin{array}{l}\bar{j} \\
\stackrel{d}{0} \\
0\end{array}$ & क्ञ & ij & $\begin{array}{l}\text { ijo } \\
\text { so } \\
00\end{array}$ & तैत्ते & \\
\hline & कि & $\overline{0} 0$ & t: & స్ & tin & $F$ & \\
\hline$\ddot{\alpha}$ & $\frac{\mathrm{d}}{\mathrm{d}}$ & है & ing & $\begin{array}{l}n \\
\infty \\
00 \\
00\end{array}$ & $2 \pi$ & 柋命 & \\
\hline N & & $\overline{0} \bar{\alpha}$ & กิ์ & $\exists=$ & 어 & 草兯 & \\
\hline & 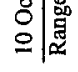 & $\begin{array}{l}1 \\
\text { If } \\
0\end{array}$ & 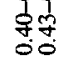 & $\begin{array}{l}1 \\
\text { bof } \\
00\end{array}$ & 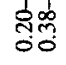 & 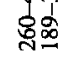 & \\
\hline 帘 & कि & \pm 0 & 50 & ㅇํㅇ & సָส & లెలి & \\
\hline & 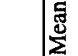 & \& f & $n_{\infty}^{\infty}$ & مْ & \begin{tabular}{l}
$\exists$ \\
$=0$ \\
\hdashline
\end{tabular} & స్రిల్ల & \\
\hline & & 윰 & 88 & 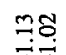 & 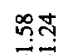 & 55 & \\
\hline & 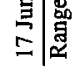 & 坣 & 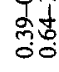 & $\begin{array}{l}7 \\
30 \\
30\end{array}$ & $\begin{array}{l}1 T \\
\infty 00 \\
\infty \\
\infty\end{array}$ & $\begin{array}{l}\text { âd } \\
\text { ôd }\end{array}$ & \\
\hline & कि & $\stackrel{0}{0}$ & 웅 & ț. & man & 架识 & \\
\hline & $\mid \frac{5}{2}$ & $\stackrel{\circ}{\varrho}$ & 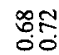 & $\underset{\substack{0 \\
=}}{=0}$ & సָత్త & పై & \\
\hline & $\begin{array}{c}\alpha \\
\alpha \\
\alpha\end{array}$ & $0 \%$ & $2 \infty$ & $\Delta \stackrel{\infty}{=}$ & 28 & 교요 & \\
\hline & 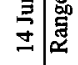 & ஸे & $\begin{array}{l}\text { भिज } \\
\text { की० }\end{array}$ & कूते & 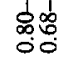 & ำ & \\
\hline 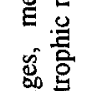 & 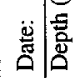 & $n$ & $n g$ & ng & $n g$ & $\begin{array}{l}\text { opo } \\
\text { do }\end{array}$ & n \\
\hline 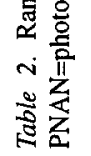 & & $\begin{array}{ll}0 \\
z \\
3\end{array}$ & 茴 & 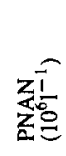 & 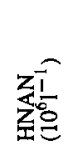 & 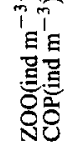 & 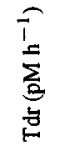 \\
\hline
\end{tabular}

\begin{tabular}{lcl}
\hline & $\begin{array}{l}\text { \% Number } \\
\text { of cells }\end{array}$ & $\begin{array}{l}\text { \% Total } \\
\text { biomass }\end{array}$ \\
\hline PNAN $5 \mu \mathrm{m}$ & $70.0 \pm 6.3$ & $23.8 \pm 5.3$ \\
PNAN 5-7 $\mu \mathrm{m}$ & $25.8 \pm 6.7$ & $40.2 \pm 10.0$ \\
PNAN $>7 \mu \mathrm{m}$ & $4.1 \pm 1.7$ & $36.0 \pm 11.0$ \\
HNAN $5 \mu \mathrm{m}$ & $85.6 \pm 6.12$ & $28.9 \pm 12.0$ \\
HNAN 5-7 $\mu \mathrm{m}$ & $10.9 \pm 5.7$ & $30.0 \pm 14.3$ \\
HNAN $>7 \mu \mathrm{m}$ & $3.3 \pm 1.9$ & $40.9 \pm 15.0$ \\
\hline
\end{tabular}

dances up to $3.3 \times 10^{3} \mathrm{cell} \mathrm{ml}^{-1}$ were observed. The range of Chl $a$ values $\left(\mu \mathrm{g} \mathrm{l}^{-1}\right)$ showed 18 and 21 fold variation within 24 hours on 14-15 and 17- 18 June 92 , respectively (Table 2 ). The low values obtained in May and June 93, were typical of oligotrophic waters (Table 2). With the exception of the period when high Chl $a$ occurred (June 92), the size-fractionated $\mathrm{Chl} a$ that the major part of the phytoplankton biomass should be attributed to $<10 \mu \mathrm{m}$ fraction (from 18 to $96 \%$, mean $63 \%$, Fig. 2). The microscopic analysis (Table 3) revealed that a mixture of flagellates $<5 \mu \mathrm{m}$ dominated PNAN population (70\%), thus confirming results of chlorophyll size-fractionation. In two occasions when bacterial production was measured (May and June 1993, Fig. 1b), two maxima were observed over each diel cycle. Thymidine incorporation rates increased between 15:00 and 18:00 and at dawn in May, while in June the increase was observed between 18:00 until 24:00 and again at dawn. The daily bacterial production calculated by integration of the diel cycle measurements was: $4.6(5 \mathrm{~m}), 4.0(40 \mathrm{~m})$ in May and $4.4(5 \mathrm{~m}), 3.6(40 \mathrm{~m}) \mu \mathrm{g} \mathrm{C}^{-1} \mathrm{~d}^{-1}$ in June. Average generation times were 3.1 days in May and 2.2 days in June.

The night and day samples, expressed as percentage of the diel means, were also compared using the MannWhitney test. The samples from dawn and dusk were discarded from the data set. Significant night-day differences were obtained only for HNAN on 14-15 June $92(t=2.2, p<0.05)$ and for bacterial abundance in December $92(t=2.0, p<0.05)$ and in June $93(t=2.0$, $p<0.05$ ).

In order to evaluate the importance of variability within and between diel studies we used a two-factor ANOVA. The factors were the diel cycles and the hours of the day; for this, the samples were coded two by two 


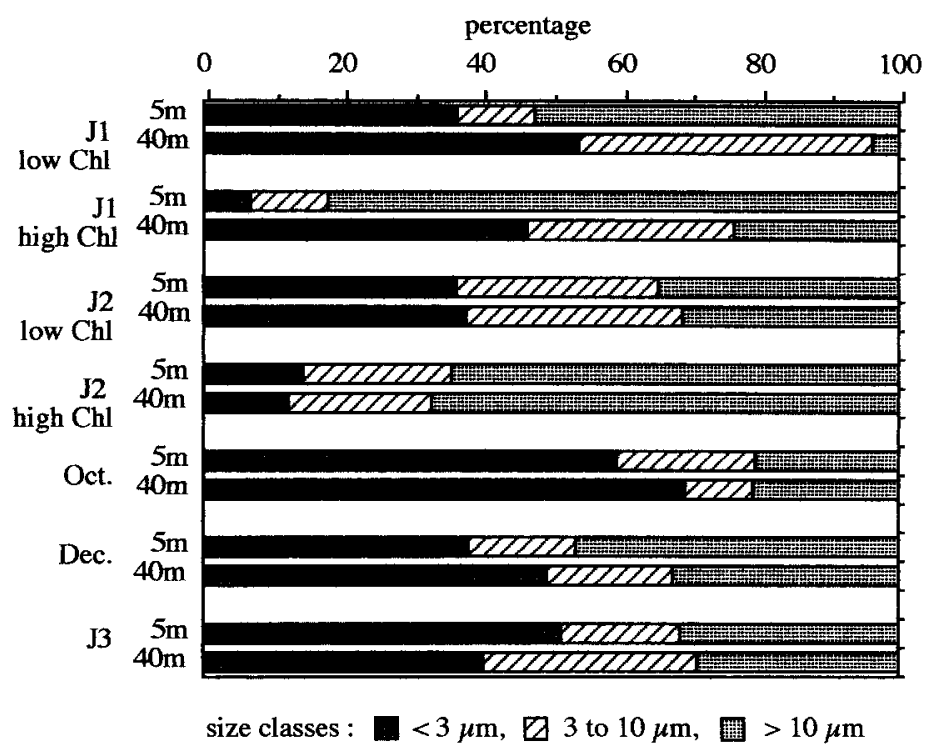

Figure 2. Relative concentrations of size fractions of Chl a (mean of diel observations). In June 92 cruises, we distinguished samples corresponding to low (low $\mathrm{Chl}$ ) and high (high $\mathrm{Chl}$ ) chloropyll $a$ and calculated the percentages separately. $\mathrm{J} 1=14-15 \mathrm{June} 92, \mathrm{~J} 2=17-18 \mathrm{June}$ 92, Oct $=$ October 92, Dec $=$ December 92, J3 = June 93 .

(comparison every six hours over each diel cycle). The variables tested (Chl $a, \mathrm{Chl} a<10 \mu \mathrm{m}$, HNAN, PNAN and $\mathrm{BACT}$ ) showed differences between cycles at $p<0.01$, while significant variability within diel cycles emerged only for Chl $a(F=5.4, p<0.05, n=52)$.

\section{Relations between organisms}

In order to investigate quantitative relationships between the different components of the food web, we calculated Spearman rank correlation coefficients for all possible pairs of variables, considering first the data of each diel cycle separately (fine scale). Few correlations were found at the $p \leq 0.05$ level, for example between zooplankton and bacterial abundance (14-15 June 92, $r=0.78$ and 26-27 June 93, $r=0.72, n=9)$ and between Chl $a$ and zooplankton abundance (10-11 October, $r=-0.73$ and 26-27 June, and $r=-0.67, n=9)$. However these correlations were not repeatedly observed. In addition variables such as HNAN and BACT, which were expected to be linked did not show any correlation. Secondly, we examined these correlations considering the whole data set (all cycles combined). In this case, the most significant correlations were found between zooplankton and bacteria $(r=0.78, n=53)$, ciliates and bacteria $(r=0.85, n=30)$, zooplankton and ciliates $(r=-0.67$, $n=30)$ and ciliates and phototrophic nanoflagellates
( $r=-0.64, n=30$ ), heterotrophic nanoflagellates were not correlated with any other variables.

\section{Distribution of particulate organic carbon}

The carbon equivalents of standing stocks were averaged for each diel cycle for the following plankton components: total phytoplankton (from total $\mathrm{Chl} a$ ), phototrophic nanoflagellates (PNAN), cyanobacteria (CYANO), bacteria (BACT), heterotrophic nanoflagellates (HNAN), ciliates (CIL) and zooplankton (ZOO). The variability of phytoplankton biomass was stronger than that of heterotrophic biomass. Except in October, when HNAN showed their maximum concentration, the bacterial biomass dominated the heterotrophic compartment (up to $38 \%$ of total biomass and up to $50 \%$ of the heterotrophic biomass). BACT:PHYTO biomass ratio ranged from 0.18 to 1.54 . The carbon equivalents (Fig. 3) and biomass ratios (Table 4), revealed that the heterotrophic biomass sometimes dominated the autotrophic biomass.

\section{Discussion}

The interpretation of plankton community structure during the 6 diel studies, in relation with hydrographic characteristics is interesting (Table 1). When the sta- 
Table 4. Percentage of the total biomass and biomass ratios (\%, mean values of 5 and $40 \mathrm{~m}$ ). BACT: bacteria; PHYTO: Phytoplankton (from Chlorophyll a); HNAN: heterotrophic nanoflagellates; PNAN: phototrophic nanoflagellates; ZOO: mesozooplankton; HETERO: sum of heterotrophic biomass; CIL: ciliates.

\begin{tabular}{lllllll}
\hline \multirow{3}{*}{ Date } & 14 & 17 & 10 & 10 & 01 & 26 \\
& June & June & Oct. & Dec. & May & June \\
& 92 & 92 & 92 & 92 & 93 & 93 \\
\hline
\end{tabular}

\begin{tabular}{llrlrrr}
\hline \% Total biomass & & & & & & \\
PHYTO & 59.5 & 55.3 & 52 & 71.3 & 24.5 & 24.8 \\
BACI & 19 & 16.4 & 15 & 12.8 & 37.2 & 38.1 \\
HNAN & 12 & 15.4 & 23.5 & 6.7 & 14.5 & 16.4 \\
CIL & 4.5 & 8.5 & 7.3 & 7.5 & 1.5 & 11.4 \\
ZOO & 5.1 & 4.3 & 2.2 & 1.7 & 22.2 & 9.4 \\
\hline
\end{tabular}

\begin{tabular}{lllllll}
\hline Biomass Ratio & & & & & & \\
BACT/PHYTO & 0.32 & 0.3 & 0.29 & 0.18 & 1.52 & 1.54 \\
BACT/HNAN & 1.59 & 1.07 & 0.64 & 1.89 & 2.56 & 2.32 \\
PNAN/HNAN & 1.21 & 0.77 & 0.59 & 2.01 & 1.63 & 1.25 \\
ZOO/PHYTO & 0.09 & 0.08 & 0.04 & 0.03 & 0.91 & 0.38 \\
HETERO/PHYTO & 0.68 & 0.80 & 0.92 & 0.40 & 3.0 & 3.0 \\
BACT/HETERO & 0.47 & 0.37 & 0.31 & 0.45 & 0.49 & 0.51 \\
\hline
\end{tabular}

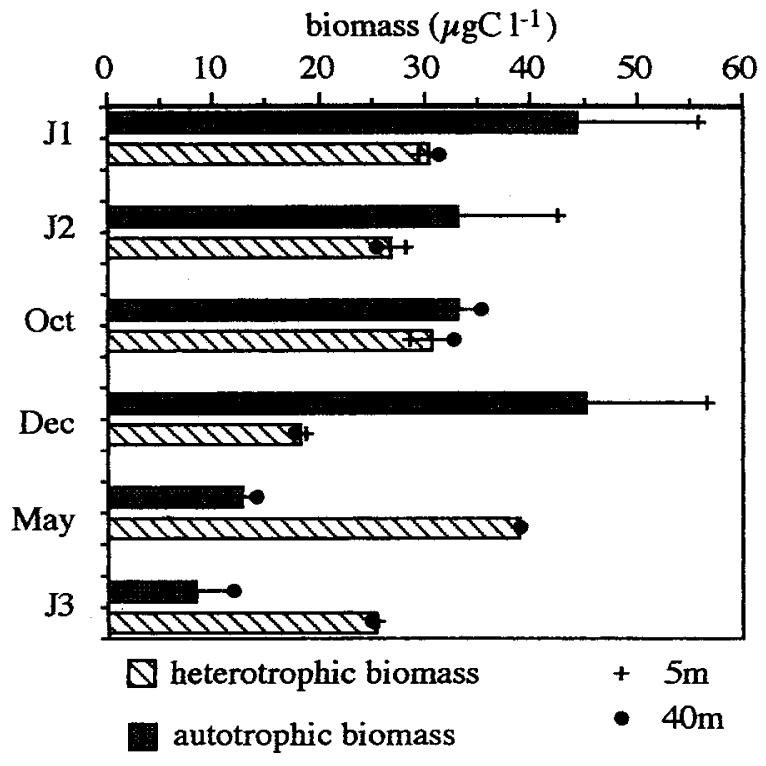

Figure 3. Sum of autotrophic and heterotrophic biomasses in each of the 6 cycles. Data of 5 and $40 \mathrm{~m}$ depths were averaged. $\mathrm{J} 1=14$ 15 June 92, J2 = 17-18 June 92, Oct $=$ October 92, Dec $=$ December 92, May $=$ May 93, $\mathrm{J} 3=\mathrm{June} 93$.

tion was located in the inner edge of the North-Western Mediterranean Current, the dominance of autotrophic biomass and occurrence of very high $\mathrm{Chl} a$ values could be explained either by the frontal influence and large mesoscale meander propagation (June 92 ), or by the coastal influences of surface waters (December 92). When the station was not within or near the current, we could distinguish two situations: (i) the current was located offshore, the station could be enriched by coastal surface waters (October 92), (ii) the current was located near the shore, the station was influenced by the oligotrophic open sea waters (May 93). Thus, the hydrodynamic processes (absence, presence and structure of the NWMC) were probably among the important factors determining the pelagic food web structure in this area.

Although marine planktonic food webs are often assumed to be pyramidal with a given biomass of autotrophs supporting successively smaller biomasses of herbivores and carnivores, situations comparable to that shown in Fig. 3 (May and June 93) are not uncommon (Holligan et al., 1984; Fuhrman et al, 1989; Piontkovski et al., 1995). In oligotrophic waters, food webs are sometimes represented by an inverted pyramid with the heterotrophic biomass dominating the autotrophic biomass (Dortch \& Packard 1989; Fuhrman et al., 1989; Cho \& Azam, 1990). Holligan et al. (1984) showed that phytoplankton was the dominant carbon component in mixed and frontal regions, whereas heterotrophic biomass exceeded that of phytoplankton in the upper layers of stratified water (Cushing 1989). Le Fèvre \& Frontier (1988) suggested that food chains dominated by herbivores develop only in 
cases when hydrodynamic processes favourable to the growth of suitable phytoplankton persist long enough. The pelagic food web structure is known to vary on large time and space scales (Cushing, 1989). Nevertheless, in the eutrophic area of the Skagerrak, Kiørboe et al. (1990) observed changes of the structure of the pelagic food chain on short distances (around $5 \mathrm{~km}$ between stations). Booth et al., (1993) in a study in the subarctic pacific report that inter-cruise variability (different days) of plankton biomass and size classes was larger than intra-cruise variability (different months or years). In this study, we also observed variability in the biomass structure on a much finer spatiotemporal scale (6 hours or $2-10 \mathrm{~km}$ considering the current speed). The ratio of heterotrophic/autotrophic biomasses varied from 0.68 to 3.0, with a strong dominance of the heterotrophic biomass under oligotrophic conditions. These values vary in a narrower range than in the surface layer $(0-50 \mathrm{~m})$ of the highly oligotrophic Sargasso sea (the ratio of bacterial biomass/phytoplankton biomass varied from 1 to 14, Fuhrman et al., 1989) and are comparable with those reported by Booth et al., (1993) in the Subarctic Pacific (heterotrophic/autotrophic biomass varied from 0.3 to 4).

Most of the times diel cycles did not show any convincing diel patterns in any of the variables studied. A classical diel migration pattern of $\mathrm{ZOO}$ with more animals in the surface layers during night hours was obtained in May and June 93 and in a lesser degree in October 92. The occurrence of the high chlorophyll values during daylight hours, especially in the 17-18 June 92 experiment, may have modified the diel spectrum of $\mathrm{ZOO}$ abundance. Higher ZOO biomasses were associated with high phytoplankton concentrations, thus masking possible migration effects. The lack of direct coupling between zooplankton and microheterotrophs, on short-term scale, maybe due to that the major part of the nanoflagellate population was too small $(<7 \mu \mathrm{m})$ to be grazed efficiently by zooplankton (Gaudy, 1974; Stoecker \& Capuzzo, 1990). The negative correlation found between COP and CIL on the seasonal scale (when the whole data set was considered, $r=-0.67$ ), suggested the existence of a predator-prey relationship (Berk et al., 1977; Sheldon et al., 1986). The impact of ZOO on BACT by excretion and sloppy- feeding processes and/or by removal of bacterivores has been demonstrated in enclosure experiments (Sheldon et al., 1986; Roman et al., 1988; Peduzzi \& Herndl 1992). The coupling of $\mathrm{ZOO}$ and BACT is also supported by the high correla- tion coefficient found between these organisms when the whole data set was considered $(r=0.78)$. Hence, the zooplankton seems to be related to the microbial food web mainly by enhancing the bacterial production through excretion and sloppy feeding (Herndl \& Malacic, 1987). Such dynamic properties of bacteria are particularly important to develop in oligotrophic conditions (Peduzzi \& Herndl, 1992). Unfortunately, rarely does environmental data provide absolute evidence for a hypothesized mechanism or theory. Nevertheless, this approach despite the possible physical, biological interactions, and difficulties of interpretation, is necessary in order to make comparisons with laboratory observations. It is however encouraging that on the two dates (May and June 93) when zooplankton showed a clear migration pattern, we observed bacterial production maxima at night and dawn. In Van Wambeke et al., (in press), we verified some of these findings through microcosm experiments realized on-board in order to minimize the noise and to establish estimates for the flow of carbon between phytoplankton, bacteria, heterotrophic flagellates, microzooplankton and copepods for the investigated region.

The variations observed in the present study revealed that an important variability of the plankton communities, may occur on a scale of $2-10 \mathrm{~km}$ (based on current speed and sampling time interval on the diel studies) even in the open sea. However, the variability in the biomass structure was probably related to phytoplankton dynamics. the higher variability of phytoplankton compared to that of heterotrophs implies that the latter are very closely coupled to their predators.

\section{Acknowledgments}

This work was supported by a Ph. D. scholarship to U.C. (CEC B/MAST/913 008), PNOC (Programme National d'Océanographie Côtière, JGOFS-France) and PLATON (French-Greek Scientific Collaboration 92 802). We are grateful to John Dolan for his help in revising the manuscript. We thank the reviewers for their constructive comments.

\section{References}

Berk, S. G., D. C. Brownlee, D. Heinle, H. L. Kling \& R. R. Colwell, 1977. Ciliates as food source for marine planktonic copepods. Microb. Ecol. 4: 27-40. 
Bochdansky, A. B., S. Puskaric \& G. J. Herndl, 1995. Influence of zooplankton grazing on free dissolved enzymes in the sea. Mar. Ecol. Prog. Ser. 12: 53-63.

Booth, B. C., J. Lewin \& J. R. Postel, 1993. Temporal variation in the structure of autotrophic and heterotrophic communities in the subarctic Pacific. Prog. Oceanogr. 32: 57- 99.

Børsheim, K. Y. \& G. Bratbak, 1987. Cell volume to cell carbon conversion factors for a bacterivorous Monas sp. enriched from seawater. Mar. Ecol. Prog. Ser. 36: 171-175.

Conan, P. \& C. Millot, Variability of the Northern Current off Marseilles, Western Mediterranean Sea, from February to June 1992. Oceanol. Acta $18(2)$, in press.

Cho, B. C. \& F. Azam, 1990. Biogeochemical significance of bacterial biomass in the ocean's euphotic zone. Mar. Ecol. Prog. Ser. 63: 253-259.

Cushing, D. H., 1989. A difference in structure between ecosystems in strongly stratified waters and in those that are only weakly stratified. J. Plankton Res. 11: 1-13.

Davis, P. G., D. A. Caron, P. W. Johnson \& J. McN. Sieburth, 1985. Phototrophic and apochlorotic components of picoplankton and nanoplankton in the North Atlantic: geographic, vertical, seasonal and diel distributions. Mar. Ecol. Prog. Ser. 21: 15-26.

Dortch, Q. \& T. Packard, 1989. Differences in biomass structure between oligotrophic and eutrophic marine ecosystems. DeepSea Res. 36: 223-240.

Eppley, R. W., S. G. Horrigan, J. A. Fuhrman, E. R. Brooks, C. C. Price \& K. Sellner, 1981. Origins of dissolved organic matter in Southern California coastal waters: Experiments on the role of zooplankton. Mar. Ecol. Prog. Ser. 6: 149-159.

Fuhrman, J. A. \& F Azam, 1982. Thymidine incorporation as a measure of heterotrophic production in marine surface waters. Evaluation and field results. Mar. Biol. 66: 109-120.

Fuhrman, J. A., R. W. Eppley, Å. Hagström \& F. Azam, 1985. Diel variations in bacterioplankton, phytoplankton, and related parameters in the Southern California Bight. Mar. Ecol. Prog. Ser. 27: 9-20.

Fuhrman, J. A., T. D. Sleeter, C. A. Carlson \& L. M. Proctor, 1989. Dominance of bacterial biomass in the Sargasso Sea and its ecological implications. Mar. Ecol. Prog. Ser. 57: 207-217.

Gaudy, R., 1974. Feeding four species of pelagic copepods under experimental conditions. Mar. Biol. 25: 125- 141.

Herndl, G. J. \& V. Malacic, 1987. Impact of the pycnocline layer on bactetioplankton: diel and spatial variations in microbial parameters in the stratified water column of the Gulf of Trieste, (Northern Adriatic Sea). Mar. Ecol. Prog. Ser. 38: 295-303.

Holligan, P. M., R. P. Harris, R. C. Newell, D. S. Harbour, R. N. Head, E. A. S. Linley, M. I. Lucas, P. R. G. Tranter \& C. M. Weekley, 1984. Vertical distribution and partitioning of organic carbon in mixed, frontal and stratified waters of the English Channel. Mar. Ecol. Prog. Ser. 14: 111-127.

Kana, T. \& P. M. Glibert, 1987. Effect of irradiances up to $2000 \mu \mathrm{Em}^{-2} \mathrm{~s}^{-1}$ on marine Synechococcus WH 7803-I. Growth, pigmentation and cell composition. Deep Sea Res. 34: 479-516.
Kiørboe, T., H. Kaas, B. Kruse, F. Møhlenberg, P. Tiselius \& G. Eertebjerg, 1990. The structure of the pelagic food web in relation to water column structure in the Skagerrak. Mar. Ecol. Prog. Ser. 59: 19-32.

Le Fèvre, J. \& S. Frontier, 1988. Influence of temporal characteristics of physical phenomena on plankton dynamics, as shown by north-west European marine ecosystems. In: Toward a Theory of Biological-Physical Interactions in the World Ocean, Rotschild, B. J. (eds) Kluwer Academic Publishers, Dordrecht 245-272.

Lee, S. \& J. A. Fuhrman, 1987. Relationships between biovolume and biomass of naturally derived marine bacterioplankton. Appl. envir. Microbiol. 53: 1298-1303.

McManus, G. B. \& J. A. Fuhrman, 1990. Mesoscale and seasonal variability of heterotrophic nanoflagellate abundance in an estuarine outflow plume. Mar. Ecol. Prog. Ser. 61: 207- 213.

Peduzzi, P. \& G. J. Herndl, 1992. Zooplankton activity fueling the microbial loop: Differential growth response of bacteria from oligotrophic and eutrophic waters. Limnol. Oceanogr. 37: 10871092.

Piontkovski, S. A., R. Williams \& T. A. Melnik, 1995. Spatial heterogeneity, biomass and size structure of plankton of the Indian ocean: some general trends. Mar. Ecol. Prog. Ser. 117: 219-227.

Riemann, B., N. O. G. Jørgensen, W. Lampert \& J. A. Fuhrman, 1986. Zooplankton induced changes in dissolved free amino acids and in production rates in freshwater bacteria. Microb. Ecol. 12: 247-258.

Putt, M. \& D. K. Stoecker, 1989. An experimentally determined carbon: biovolume ratio for marine 'oligotrichous' ciliates from estuarine and coastal waters. Limnol. Oceanogr. 34: 1097-1 103.

Roman, M. R., H. W. Ducklow, J. A. Fuhrman, C. Garside, P. M. Glibert, T. C. Malone \& G. B. McManus, 1988. Production, consumption and nutrient cycling in a laboratory mesocosm. Mar. Ecol. Prog. Ser. 42: 39-52.

Sheldon, R. W., P. Nival \& F. Rassoulzadegan, 1986. An experimental investigation of a flagellate-ciliate-copepod food chain with some observations revelant to the linear biomass hypothesis. Limnol. Oceanogr. 31: 184-188.

Sorokin, Yu. I., A. I. Kopylov \& N. V. Mamaeva, 1985. Abundance and dynamics of microplancton in the central tropical Indian Ocean. Mar. Ecol. Prog. Ser. 24: 27-41.

Stoecker, D. K. \& J. M. Cappuzo, 1990. Predation on Protozoa: its importance to zooplankton. J. Plankton. Res. 12: 891-908.

Strickland, J. D. H. \& T. R. Parsons, 1972. A practical hand-book of seawater analysis. 2nd ed. Bull. Fish. Res. Bd Can. 167: 1-311.

Utermöhl, H., 1958. Zur Vervollkommnung der quantitativen Phytoplankton Methodik. Mitt. int. Ver. Limnol. 9: 323-332.

Van Wambeke, F., U. Christaki \& R. Gaudy. Carbon fluxes from the microbial food web to mesozooplankton. An approach in the surface layer of a pelagic area (NW Mediterranean Sea). Ocean. Acta, in press. 